Review Article

\title{
POLLEN FROM GENETICALLY MODIFIED PLANTS IN HONEY - PROBLEMS WITH QUANTIFICATION AND PROPER LABELLING
}

\author{
Ewelina Żmijewska \\ Dariusz Teper ${ }^{2}$ \\ Anna Linkiewicz ${ }^{1 *}$ \\ Sławomir Sowa' \\ 'GMO Controlling Laboratory, Department of Plant Biotechnology and \\ Cytogenetics, Plant Breeding and Acclimatization Institute - National Re- \\ search Institute, Radzików, Poland \\ ${ }^{2}$ Research Institute of Horticulture, Apiculture Division, Puławy, Poland \\ *corresponding author: a.linkiewicz@ihar.edu.pl \\ Received 02 August 2013; accepted 27 November 2013
}

\begin{abstract}
A bstract
Maize can be a valuable source of pollen when plants attractive for bees are not available. Honeybees can forage from conventional maize as well as from genetically modified (GM) maize. The Court of Justice of the European Union (EU) ruled that pollen in honey must be treated as a food ingredient and therefore falls within the scope of Regulation $1829 / 2003 / E C$ on GM food and feed and requires authorization. GM pollen unauthorized in the EU cannot be present in honey at any level, and honey must be labelled if it contains more than $0.9 \%$ of pollen from authorized $\mathrm{GM}$ plants in relation to total pollen content. However, currently available analytical methods allow only for estimation of GM pollen quantity in honey. Therefore, Directive 2001/110/EC related to honey needs to be amended so that pollen can be regarded as a natural constituent of honey. Because the $\mathrm{EU}$ is a big honey importer, validated and harmonized detection methods are necessary for the control of GM pollen in honey.
\end{abstract}

Keywords: GMO, honey, labelling, maize, pollen.

\section{INTRODUCTION}

The honeybee is inextricably linked with entomophilous spermatophyte plants, which are the main source of the energy (nectar) and protein (pollen) for honeybees that are necessary for rearing the next generations of bees. However, worker honeybees frequently visit the flowers of anemophilous plants and gather only pollen (Prabucki, 1998). The attractiveness of these plants depends primarily on their pollen efficiency, which is usually higher than that of entomophilous taxa. Maize (Zea mays L. subsp. mays group Saccharata) has a pollen efficiency of $173 \mathrm{~kg}$ pollen/ha (Nowakowski and Morse, 1982).

Since implementation of the European Union (EU) Regulation 1829/2003/EC on genetically modified (GM) food and feed, pollen in honey has been classified as a natural component, and honey containing GM pollen has not required labelling. Recently, however, this situation changed because the Court of Justice of the European Union (ECJ) judged that pollen is a honey ingredient and that honey containing GM pollen can be placed on the market only if GM pollen has been authorized as food and proper labelling is in place (Court of Justice, 2011).

The EU accounts for around $13 \%$ of global honey production (200,000 tonnes), where the largest producer is Spain (33,000 tonnes), followed by Italy, Hungary, Romania (each produce around 22,000 tonnes), and Portugal (21,000 tonnes) (European Commission, 2012a). Honey production in the EU is not sufficient for consumption and industry needs. Therefore, approximately $40 \%$ of honey used in the EU is imported from third-party countries (European Parliament, 2013). ManyGMplants(maize, cotton, soybean, sugar beet, rapeseed) are cultivated 
outside the EU but are authorized in the EU for food purposes, and food products containing pollen from these plants must be labelled as GM organisms (GMOs). Currently, only one GM crop is cultivated in the EU on a commercial scale: more than 240 varieties of GM MON 810 maize suited for different climatic conditions can be found in the Common Catalogue of varieties of agricultural plant and vegetable species. Almost all EU countries grow maize for a total area of EU maize cultivation of about 9.8 million ha, which represents $13.9 \%$ of all cereal, oilseed, and protein crop area (European Commission, 2013a). In 2012, six EU countries (Spain, Portugal, Czech Republic, Slovakia, Poland, and Romania) cultivated GM maize on 129,071 ha, with Spain growing $90 \%$ of the total GM maize hectarage (James, 2013). Because bees can collect pollen from conventional as well as from GM maize (Lipiński et al., 2008), cultivation of MON 810 maize in the EU can potentially affect the honey industry in terms of GMO labelling and coexistence measures. Asynchronous authorization of GMOs in the EU and third-party countries creates additional problems with imported honey, which can contain pollen from GM plants not authorized in the EU.

According to beekeeping practice, pollen should not be treated as an ingredient of honey but as a component because it enters honey naturally. Moreover, analytical methods used for GMO detection do not allow for proper quantification of GM pollen in honey according to current legal requirements. The aim of this article is to discuss current problems with proper labelling of products containing pollen from GM plants and to highlight the need for amendments to the EU regulations related to honey.

\section{Decision of the European Court of Justice regarding pollen in honey}

In September 2011, the ECJ decreed that pollen is an ingredient of honey, not a natural component. This decision was an outcome of the legal proceedings of a German beekeeper against the state of Bavaria in Germany. In 2005, this beekeeper had hives located $500 \mathrm{~m}$ from a GM maize MON 810 trial field belonging to the Bavarian government. In the samples of honey and pollen collected from his hives, DNA and proteins from GM maize were detected (Court of Justice, 2011; Davison, 2011).

The ECJ reclassification of pollen caused problem for producers and retailers, so that honey containing pollen of GM plants had to comply with the Regulation 1829/2003/EC on GM food and feed. It requires that any GMO to be used as a food or feed has to go through an approval process, proving that it is safe for humans, animals, and the environment. These regulatory changes have widespread consequences for the testing and approval required to deliver agricultural products to consumers and markets (Davison, 2011). Fortunately, more recently, work has gotten under way on the revision of the Council Directive 2001/110/EC related to honey, according to which pollen will be considered a natural component of honey (European Commission, 2012b).

\section{Possible sources of pollen in honey}

The presence of pollen in honey results from a natural process of honey production by bees (Bryant and Jones, 2001). Bees collect nectar from melliferous plants. If anthers are situated sufficiently close to nectaries, nectar is easily contaminated by loose pollen. This contamination is further facilitated by gusts of wind and the fact that flowers are visited by insects that knock the pollen into the nectar. The nectar containing pollen is subsequently harvested by worker honeybees into their honey sacs and transported to the hive.

Another source of pollen in honey is honey extraction from the combs that contain bee bread cells (Fernandez and Ortiz, 1994). In the course of a traditional apiary cycle, beekeepers create fresh frames with embedded foundations (thin sheets of wax with foundations of cells embedded on their surfaces) to equalize the swarming tendency during the period of intensive growth of bee colonies. If a bee colony becomes so large that the combs fill the whole interior of the beehive, it is necessary to remove a few combs from the hive and transfer them to the part of the hive that exclusively contains honeycombs. This transfer requires the use of combs containing the so-called capped brood, 
around which bee bread cells are usually located. Young bees leave the cells after a few days, and empty or partially filled bee bread cells are filled with nectar. The bee bread softens because nectar and later honey contain water. During the extraction process of honey from combs, the bee bread falls outside the comb, causing additional contamination of honey with pollen. If, in addition to pollen of nectariferous plants, the bee bread contains pollen from non-melliferous plants, such as maize pollen, there is a high risk that it will contaminate the honey.

Some amount of pollen from anemophilous plants gets into the honey together with honeydew that sometimes develops profusely on the leaves of certain trees, such as Tilia spp., Acer spp., Quercus spp., Picea spp., Abies spp., and Larix spp. Pollen easily adheres to the honeydew, and maize pollen also can be found among these grains.

Studies carried out by Wysocka (2009) confirmed that bees gather pollen from both conventional and GM maize varieties. Similarly, studies conducted by Hofmann et al. (2010) showed that honeybee workers visit GM maize varieties for harvesting pollen.

Currently, the most frequently chosen method to determine the botanical origin of apicultural products is pollen analysis. This analysis enables identification of the plant species that bees visit, based on the characteristic species-specific features of pollen grain structure. Palynological analysis of honey is performed to estimate the percentage of nectar gathered from various species of nectar-generating plants (Louveaux et al., 1970; Ricciardelli d'Albore, 1997). Pollen grains from plants that do not generate nectar, such as maize, are not included in this analysis, but are calculated separately (Bryant and Jones, 2001).

The above-mentioned data indicate that maize can be a valuable source of pollen for bees when fields of this crop are located within their flight range. In light of the widespread cultivation of maize in EU countries, it must be assumed that apicultural products, including honey, produced within the EU territory can contain maize pollen.

\section{Maize pollen in honey - results of studies in Poland}

The maize blossoming period in the territory of Poland falls during the time of year in which there is shortage of nectar, pollen, and honeydew in many parts of the country. It is also the period of intensive brood breeding, which contributes to the fact that bees regard maize pollen as particularly attractive. Maize has a high efficiency of pollen production, especially during the phase of bee larvae development (Maurizio, 1951). Maize pollen also is among the most nutritious pollens, with a relatively high protein content (23.9\%) (Roulston et al., 2000).

On the basis of different publications on palynological analyses of honey, bee bread, and pollen loads, it can be concluded that maize pollen can be present in apicultural products (Fig. 1) and that its content in the analysed samples may vary. Wróblewska (2002) reported that of 200

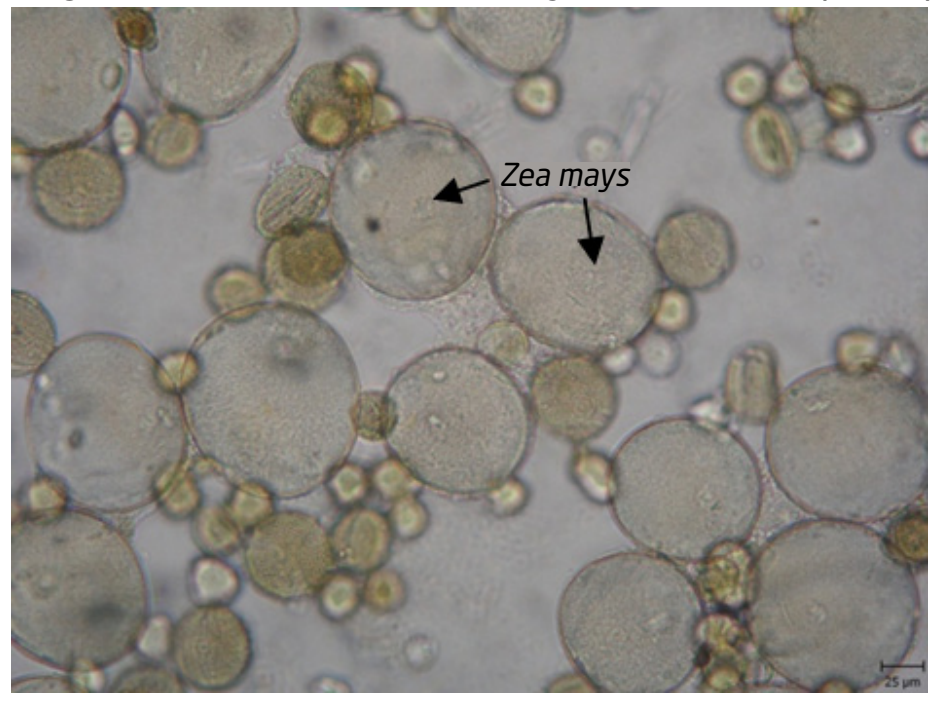

Fig. 1. Microscopic image of honey with maize pollen grains. 
honey samples gathered in the Podlasie region, $8 \%$ contained pollen from maize, and maize pollen represented $16 \%$ of total anemophilous plant pollen found in the honey. In the same study, $11 \%$ of 54 samples of bee bread contained maize pollen. Stawiarz and Wróblewska (2010) claim that $30 \%$ of 73 samples of multifloral honey from the Wyżyna Sandomierska region contained maize pollen. The maize pollen was present in $<5 \%$ of bee bread samples originating from the Lubelskie voivodeship, and it represented less than $3 \%$ of total pollen grains (Wróblewska et al., 2010).

Maize pollen can be an important source of feed for honeybees, especially when the apiaries are located in proximity to large maize fields. Maize pollen collected by foraging bees is mainly used as feed for other bees and for brood cells; therefore, it is relatively rare in honey, and maize is classified as a minor pollen species.

\section{Current status of GM crop cultivation}

The large-scale cultivation of GM crops began in 1996, with a total area of 1.7 million ha. The area planted with GM crops increased 100 -fold during the intervening 16 years, reaching 170 million ha in 2012. This trend continues, with a 6\% increase in cultivation area in 2012 as compared to 2011 (James, 2013). The most prominent GM crop varieties under cultivation are those tolerant to herbicides, followed by those resistant to pests. In 2011, GM soybean occupied 75.4 million ha or $47 \%$ of the global area planted with GMO; GM maize occupied 51 million ha or $32 \%$ of the global area; GM cotton occupied 24.7 million ha or $15 \%$ of the global area; and GM canola occupied 8.2 million ha or $5 \%$ of the global area under cultivation with GM crops (James, 2012).

In the EU, 47 different modifications are authorized for use as a food and feed, but only two GM plants are authorized for cultivation: the MON 810 Bt maize and the potato EH 92-527-1 Amflora. Amflora potatoes produce pure amylopectin starch, which is used for industrial processing. MON 810 maize contains the cry $1 \mathrm{Ab}$ gene from the bacterium Bacillus thuringiensis, which encodes the Bt toxin that acts as an insecticide against Lepidoptera. Recently, the
Polish government accepted regulations prohibiting the use of GM seeds of MON 810 maize and the Amflora potato varieties in accordance with the Polish Seed Act (Ustawa o nasiennictwie, 2012). On 28 January 2013, Poland joined other EU Member States (Austria, Germany, France, Greece, Hungary, and Luxembourg) that banned the use of MON 810 and Amflora seeds.

\section{The EU regulation system for GMOs in food, feed, and environment}

The EU has a complex system for authorization of GMOs for import, processing, and use as food or feed and cultivation. The authorization process for GMOs as food is based on the Regulation 1829/2003/EC for GM food and feed. It covers a GMO and food containing or consisting of that GMO, as well as food produced from or containing ingredients produced from that GMO. The European Food Safety Authority (EFSA) issues a specific safety assessment for the GM product, which focuses on impact on human and animal health and on the environment (European Food Safety Authority, 2011). Based on the EFSA assessment, the European Commission (EC) together with the EU Member States decides whether or not to authorize a GM product. The authorization process carried out by the EU is considered to be very strict, and the resulting decision applies to all EU Member States.

The EU has stated that the rules of coexistence include "the ability of farmers to make a practical choice between conventional, organic, and GM crop production, in compliance with the legal obligations for labelling and/ or purity standards". On 13 July 2010, the EC issued a recommendation on guidelines for the development of national coexistence measures to avoid the unintended presence of GMOs in conventional and organic crops (European Commission, 2010). Coexistence enables farmers to avoid the unintended presence of GMOs in a food chain. Many studies have been performed to assess the practicality of coexistence and to suggest coexistence measures that can be implemented in practice (e.g., Messean et al., 2006). Coexistence laws with technical and administrative requirements for GM farmers 
exist in most EU countries, and they can be highly variable depending on environmental factors and the agriculture production systems. The most important measure is field isolation. Many EU Member States have adopted coexistence measures for $\mathrm{Bt}$ maize with different isolation distances ranging from $25 \mathrm{~m}$ to $600 \mathrm{~m}$. However, concerns have been raised that the EU coexistence rules are not stringent enough to prevent the presence of GM pollen in apicultural products (Schiemann, 2011).

In November 2012, during the Plenary Meeting of the European Coexistence Bureau, it was agreed that the monitoring of the efficiency of coexistence measures in respect to their potential to reduce adventitious presence of GM maize should be done at the field level. The adopted strategy takes into account beekeeping

1

Sampling of honey

Isolation of pollen

2

DNA extraction

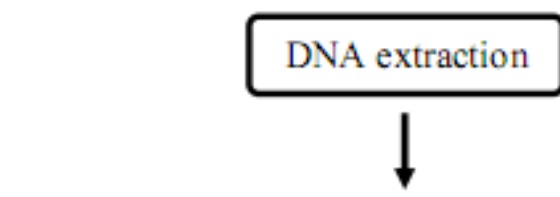

GMO PCR screening

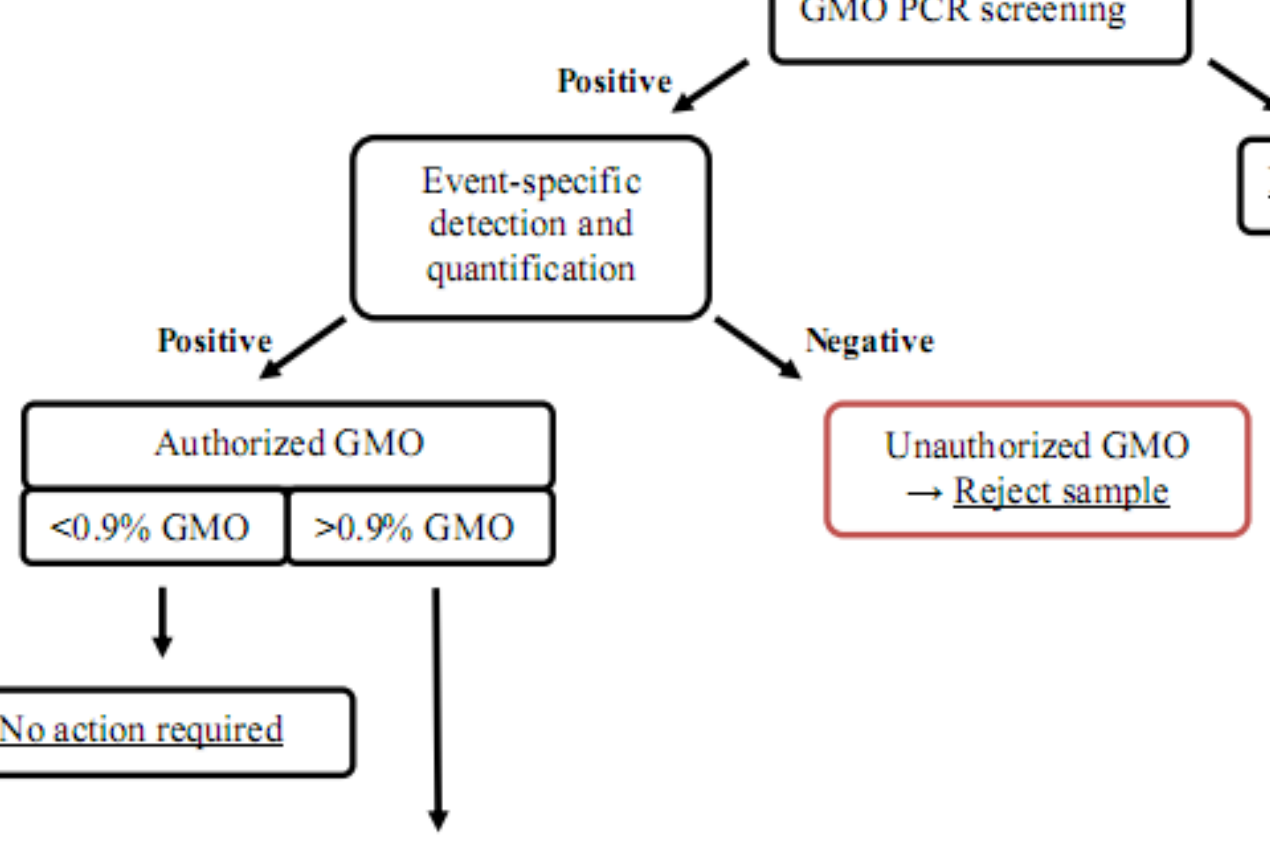

No action required

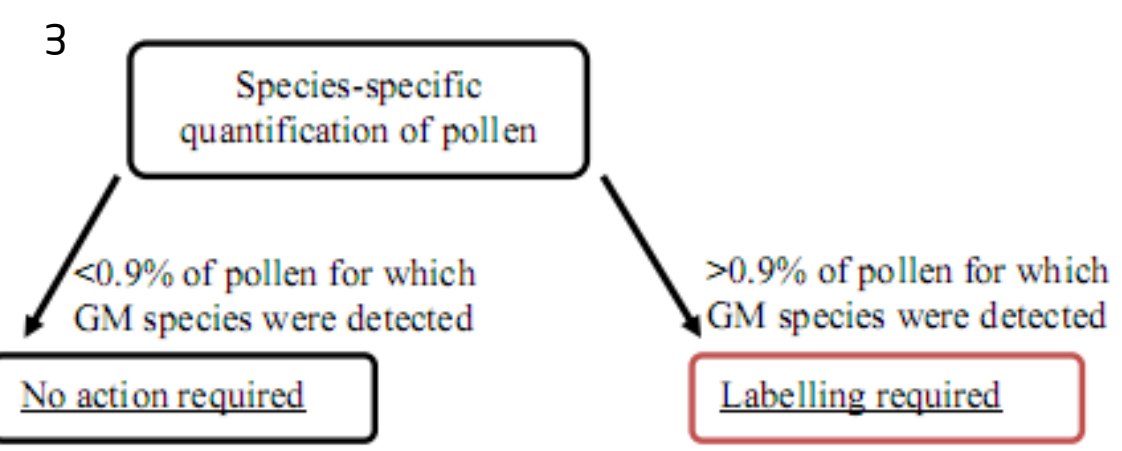

Fig. 2. Example of honey analysis for GMO quantification. 
in the EU, honeybee foraging behaviour, effects of honeybee foraging behaviour on maize, foraging distances, and the location and size of the monitored fields in relation to the GM maize area (European Coexistence Bureau, 2013). According to the Regulation 889/2008/EC laying down detailed rules for the implementation of Regulation 834/2007/EC on organic production and labelling of organic products, the hives shall be located within a radius of $3 \mathrm{~km}$ from the apiary site, and nectar and pollen sources consist essentially of organically produced crops and/or spontaneous vegetation and/or crops treated with low environmental impact methods. This radius is approximately three times more than typical honeybee flying distances. Analogical strategy applied to conventional honey production and GM fields would minimize the risk of GM pollen presence in honey.

\section{Unauthorized GMOs in honey}

Europe is a significant honey importer. The EU imports about 140,000 tonnes of honey mainly from Argentina (about 40,000 tonnes) and China (about 33,000 tonnes). In both of these countries, GM varieties that are not authorized in the EU are cultivated. Honey is also imported to the EU from other countries cultivating GM crops such as Mexico, the USA, Canada, and Brazil (Filodda, 2011). Large-scale GM plantations in those countries and especially the unauthorized GMO (UGMO) varieties may threaten honey import into the EU market.

Possible sources of UGMOs can be "asynchronous" authorization, as GMO can be authorized for commercial use as food or feed in a thirdparty country but not in the EU. Another source of UGMOs can be "escapes" of GM material from field trials and laboratories, or intended illegal releases (Holst-Jensen et al., 2006).

To detect unauthorized GM pollen in honey samples, it is necessary to develop methods that allow for extraction of good-quality DNA in amounts sufficient to perform proper PCR screening and event-specific tests.

\section{GMO labelling in food}

In the EU, labelling of GM food has been mandatory since 1997. In April 2004, a new Regulation 1829/2003/EC on GM food and feed entered into force. The authorization of MON 810 maize for food and feed had not previously included pollen. In 2011, the EFSA published on request from the $E C$ a scientific opinion on the safety of MON 810 maize pollen occurring in or as food. EFSA concluded that the genetic modification in MON 810 maize would not constitute an additional health risk if MON 810 maize pollen were to replace maize pollen from non-GM maize in or as food (European Food Safety Authority, 2011). The decision authorizing pollen produced from MON 810 maize was adopted on 6 November 2013 by the EC. This authorization is valid for 10 years, and food products produced from or containing MON 810 pollen are subject to the EU's strict labelling and traceability rules (European Commission, 2013b).

According to the Regulations 1829/2003/EC and 1830/2003/EC, a labelling threshold of $0.9 \%$ applies only if the presence of GMO based on each of the ingredients considered individually is adventitious or technically unavoidable. So far, pollen has not been regarded as a honey ingredient because it is a natural component that enters honey during production.

The ECJ confirmed the policy of zero tolerance for traces of GM material that does not have the necessary authorization.

In September 2012, the EC proposed to amend Council Directive 2001/110/EC and define pollen as a natural constituent, not an ingredient of honey (European Commission, 2012b). Still, honey containing GM pollen could be placed on the market only if GM pollen is covered by an authorization, and the labelling rules on GMO in food will apply. The Directive 2001/110/EC provides detailed criteria for honey quality. According to them, one of the most important requirements for honey is the limit of water-insoluble content (pollen, honeycomb fragments, bee, and dirt elements). The required limits for such content are in general less than $0.1 \mathrm{~g}$ per $100 \mathrm{~g}(0.1 \%)$, with the exclusion of "pressed honey" in which the limit is $0.5 \mathrm{~g}$ per $100 \mathrm{~g}(0.5 \%)$. Consequently, every maize pollen grain in honey is considered 


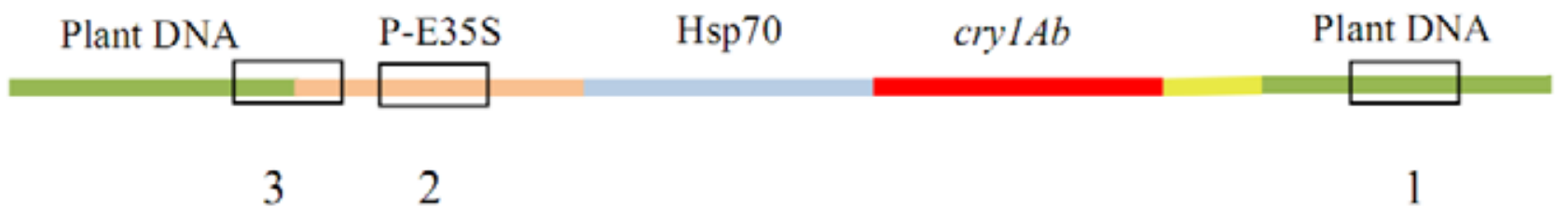

Fig. 3. PCR analysis scheme targeting different DNA construct elements for detection and identification of GMOs; an example of the MON 810 event.

1. Plant-specific test. In the absence of amplifiable DNA from a particular plant species, tests confirmed the presence of amplifiable DNA

2. Screening test

3. Event-specific test

as a water-insoluble part, which should not exceed required limits. Existing data show that total pollen content in honey varies from $0.003 \%$ to $0.104 \%$ (Piazza and Persano Oddo, 2004). Such quantities of pollen in honey would not exceed the mandatory labelling threshold for GM food ( $0.9 \%$ of the total weight of honey).

\section{Detection and quantification of GM pollen in honey}

According to the ECJ decision, the pollen of GM plants in honey must be classified as an 'ingredient'. The percentage of GM pollen in honey should be presented as the ratio of the number of pollen grains from GM crops to the total number of pollen grains. So far, routinely used GMO quantification methods are based on real-time PCR techniques (Ciabatti et al., 2006). Real-time PCR quantifies GM DNA in the sample with respect to a species-specific reference sequence (Chouachi et al., 2008a; Chouachi et al., 2013). This technique was used for quantification of pollen-mediated gene flow from MON 810 maize to conventional maize (Pla et al., 2006) and to detect airborne MON 810 maize pollen (Kluga et al., 2012). However, real-time PCR cannot differentiate between a DNA sequence from GM pollen and a GM DNA sequence from other plant parts that can be present in honey. Most of the honeys contain a mixture of pollen from different plant species. To date, pollen-specific DNA sequences have not been described. Therefore, to determine the pollen grain number of a particular species, microscopic analysis is used. The combination of a real-time PCR technique and palynological analysis allows only for estimation, not precise determination of the quantity of GM pollen in honey.
An example of the analysis of GM pollen in honey is shown in Figure 2. Each quantification process is built from several steps that include (1) sampling (comprising homogenization) and pollen isolation; (2) molecular analysis (DNA extraction; PCR-based screening test and event-specific test); and (3) microscopic analysis (species-specific quantification of pollen).

\section{1) Sampling of honey and pollen isolation}

The first step of honey analysis is sampling. This step is the most critical in the analytical process, especially when the pollen is not homogeneously distributed in the lot, which is typical for a GMO (Ancel et al., 2009). The sampling step should be done as precisely as possible to collect a representative sample from the batch and thus obtain the most accurate value (Paoletti et al., 2003; Bellocchi et al., 2009). Pollen grains are unequally distributed in honey, and only a few of them might be derived from GM plants (Bobis et al., 2012). There are no international standards that address the uncertainty of nonhomogeneous pollen distribution in large-scale samples.

The second step of sampling covers the isolation of pollen from the homogeneous honey sample. This task is challenging because honey contains very small amounts of pollen (Sawyer, 1988). Centrifugation (according to German Standard DIN 10760) or filtration (not standardized) methods are generally used for the isolation of pollen from honey (Cheng et al., 2007; European Union Reference Laboratory, 2012).

The number of pollen grains from an individual plant species that are present in honey determines the amount of extractable DNA for that species. Maize pollen is usually only an additional source of food for bees; therefore, 
it is present in low amounts in honey when compared to pollen from melliferous plants (Sabugosa-Madeira et al., 2007; Wróblewska et al., 2010).

Honey is a difficult matrix for plant DNA extraction because of the variable number of pollen grains. Honey contains a composite mix of various organisms: bees, bacteria, and fungi. Furthermore, frequent contamination by plant parts occurs in honey (Schnell et al., 2010; Olivieri et al., 2012). After extraction, it is not possible to separate pollen DNA from the total DNA. In addition, honey contains up to $83 \%$ sugars that can hinder DNA extraction, so the separation of sugars from DNA is crucial (Cheng et al., 2007). The acidity (pH value of approximately 3.9) and high viscosity (2 - $\left.10 \mathrm{~N} \cdot \mathrm{s} / \mathrm{m}^{2}\right)$ of honey also complicate DNA extraction.

In palynological analysis, samples of $10 \mathrm{~g}$ are routinely used for both quantitative and qualitative pollen analyses of honey. In the case of quantitative pollen analysis, the laboratory honey sample must be homogenized by heating and stirring for a few minutes. The sample does not require homogenization before performing qualitative pollen analysis.

The qualitative pollen analysis of honey allows determination of the source of nectar for honeybees while quantitative pollen analysis allows determination of the number of speciesspecific pollen grains in honey. This parameter is specific to each type of unifloral honey. With this method, it is possible to estimate the level of maize pollen admixture in honey.

\section{2) PCR analysis}

\section{a) DNA extraction}

The major challenge for detection of GMOs in the honey matrix is DNA extraction. The quality, purity, and concentration of DNA are crucial factors that determine the detection and quantification limits of the analyses.

An effective method of disrupting a very hard pollen outer layer - exine - is an important step for efficient DNA extraction. Mechanical pre-treatment is more effective than chemical disruption (Brodman, 2008). Few protocols and methods are available for the extraction of plant DNA from honey. The German Federal Office of
Consumer Protection and Food Safety published guidelines for sampling and analysis of GM pollen in honey (German Standard DIN 10742:2011). An inter-laboratory validation of a method for DNA extraction from pollen in honey was conducted in 2012 and confirmed that amplifiable plant DNA can be extracted from unifloral or multifloral honey in this way (Waiblinger et al., 2012). The European Union Reference Laboratory for Genetically Modified Food and Feed (European Union Reference Laboratory, 2012) has published a procedure for pollen DNA extraction from honey. Validation of MON 810 maize DNA quantification was performed on honey spiked with different MON 810 pollen concentrations. The limit of quantification was estimated at the level of $0.1 \%(w / w)$. Cheng et al. (2007) described the DNA extraction procedure from honey and a PCR protocol for the detection of Bt cotton DNA sequences by a qualitative PCR test. Efficient DNA extraction from honey is not only necessary for GMO identification but also for the detection of plant species and pathogens (Dobbelaere et al., 2001; Piccini et al., 2002; Olivieri et al., 2012). In response to market requirements, biotechnology companies offer commercial kits for DNA extraction from honey (e.g., Biolytix Preparation and DNA Extraction, Qiagen DNA Extractor Honey). Honey contains a significant number of PCR inhibitors, and purification of the extracted DNA is recommended. The isolated DNA must be of high quality for reliable PCR analysis.

\section{b) Screening and quantification of GMOs}

The detection of GM material is done at the DNA level by measuring the presence of DNA transgenes and/or by detecting the presence of transgenic proteins (Linkiewicz et al., 2006; Žel et al., 2012). For honey analysis, a PCR-based test is used. The test detects specific DNA fragments present in the GMO (Grohmann et al., 2009; Eichner, 2011). The primary test, called 'screening', detects the most common elements routinely used in the DNA constructs for transformations such as promoter, terminator, or marker genes. In a multiplex approach, a set of simplex real-time PCR systems targeting different elements (endogenous sequences, 
genetic markers, and GM-specific elements) is chosen in a system that allows for detection of multiple GMOs in a single analytical run (Querci et al., 2009; Kluga et al., 2012, Mano et al., 2012). In the case of MON 810, analysis sequences of the npt-II marker gene and regulatory P-E35S promoter are targeted (Chaouachi et al., 2008b) (Fig. 3).

To confirm the presence of amplifiable DNA, a PCR test can be used that amplifies a plantspecific DNA sequence, such as the $\beta$-actin gene (ACT) (Laube et al., 2010), chloroplast DNA, or nuclear ribosomal small subunit genes (such as 18S). To confirm the presence of maize, the following genes can be used: the high-mobility group gene (hmg), the alcohol dehydrogenase-1 (Adh1) gene, the maize starch synthase gene (zSSIlb), and the invertase gene (ivr1) (Broothaerts et al., 2008; Scholdberg et al., 2008).

The event-specific analysis has higher specificity and targets the sequence of the transgene integration border region (Fig. 3). Quantitative PCR (qPCR; real-time PCR) methods are routinely used for quantification of GMO in various food products. Analysis of qPCR fulfils the EC recommendation 2004/787 (European Commission, 2004), which states that the presence of GMO material should be expressed as 'the percentage of GM DNA copy number in relation to target taxon-specific DNA copy number calculated in terms of haploid genomes' and compared to the ratio for certified reference material of known GM content. The percentage of GMO in the sample is presented as the ratio of the copy number of the GM-specific DNA sequence to the copy number of the reference gene sequence that is specific for the analysed species [100 $\times$ (GM/reference)] (Žel et al., 2012). The result on the label indicating percentage of GMO is a sum of detected GM events for the particular plant species (e.g., maize).

If the food sample contains authorized GMOs, then the amount of GMOs must be determined by the event-specific method, typically covering part of the host genome with the inserted recombinant sequence (Fig. 3) using, for example, validated methods from the EU Reference Laboratory for GM Food and Feed (European Union Reference Laboratory, 2012; Scholtens et al., 2010, Ciabatti et al., 2006). If the food sample contains an unauthorized GMO, quantitative analysis does not need to be performed because such products cannot be present on the market.

\section{3) Species-specific quantification of pollen using microscopy}

Microscopic palynological analysis is used for the estimation of honey origin. It allows the identification of pollen grains from particular plant species and quantification of pollen grains in a honey sample. Qualitative pollen analysis (verification of honey species) in all countries is performed according to the method of Louveaux et al. (1978). Quantitative pollen analysis is performed by counting all pollen grains in 1 or $10 \mathrm{~g}$ of honey (Louveaux et al., 1978), which allows calculation of the abundance of anemophilous pollen grains (including maize pollen) that have gotten into the honey with bee bread. The International Commission of Bee Botany recommends qualitative and quantitative methods for pollen analyses (Von der Ohe et al., 2004).

\section{Combining PCR and microscope-based methods for GM pollen quantification}

Having in mind current method limitations and the EC] decision that pollen is treated as a food ingredient, it is important to emphasize that available methods allow only for estimation of the percentage of GM pollen in the total pollen content. So far, none of the above-mentioned methods (real-time PCR, palynological analysis), when applied separately, allow for quantification of GMO in honey. The only alternative for the estimation of GMO is to combine the results of PCR and microscope-based methods. The results of PCR analysis give information only about the percentage of GM modification in relation to a particular species. The proposed method is not accurate because it is not possible to determine the precise quantity of GM pollen in a sample. Quantitative microscopic pollen analysis gives information about the number of pollen grains of particular species in honey; however, palynological analyses are not useful for differentiation between wild-type and GM 
pollen. Therefore, even the combination of quantitative PCR and palynological methods allows only for the estimation of GM pollen content in honey, not for the precise determination of GM maize pollen in honey.

Three strategies for quantification of GM pollen in honey are proposed, but none of them is precise enough to meet the minimal performance criteria for the official control of GMO. The first approach is based on the "worst case" assumption that honey may contain GM pollen as well as other parts of GM plants (Eichner, 2011). Because PCR quantification of GMO is based on all DNA isolated from honey, it is not possible to estimate the share of GM pollen in the total GMO quantity. Therefore, if GM maize and maize pollen are detected in the sample, the assumption that all maize pollen comes from GM plants is made. Labelling is required if the maize pollen was detected in the honey sample at a level of at least $0.9 \%$ in relation to the total number of pollen grains and authorized GM maize content in the sample reached $0.9 \%$.

The second approach is based on the assumption that GMO quantified by quantitative PCR in honey comes from GM pollen only. If the honey sample contains $5 \%$ of authorized GM maize and maize pollen accounts for $10 \%$ of total pollen, the result should be expressed as $10 \% \times 0.05$ $=0.5 \%$ of GM maize pollen in relation to total pollen in honey. This value is less than $0.9 \%$, and this honey would not need to be labelled (Lanzelotti, 2011).

The approach includes the classical calculation of GMO concentration as a percentage of GM DNA copy number in relation to target taxonspecific DNA copy number calculated per haploid genome equivalent (for example, percentage of the MON 810-specific sequence copy number to the copy number of the maize-specific hmg gene). In that case, GM pollen quantification is possible only in relation to the total amount of particular species in honey.

\section{SUMMARY}

Maize can be an attractive source of pollen for honeybees in case of shortage of entomophilous plants. Honeybees can forage for conven- tional maize, as well as GM maize. According to the judgment of the European Court of Justice- Case C-442/09, pollen from GM plants present in honey must be treated as a food ingredient and requires authorization. In the European Union, labelling requirements apply to all GM food. Food containing less than $0.9 \%$ of authorized GMO per ingredient does not have to be labelled only if the GMO presence is adventitious or technically unavoidable. Development of methods for good-quality DNA isolation from honey is necessary for PCR-based identification of GMO. The proposed quantification of GM pollen in honey is based on the combination of molecular and palynological methods, but currently available methods used for GMO quantification even when combined with palynological analysis do not allow for the precise quantification of GM pollen in honey. These issues pose a problem in terms of routine GM food control performed by enforcement laboratories in EU countries as well as for the harmonization of GMO control at the global level. Because of difficulties in detection of unauthorized GMOs in honey, suitable methods are necessary for DNA extraction as a key step in quantifying GM pollen. Alternatively, new analytical methods that allow quantification of GM pollen in total pollen should be developed. Because the current advances in GMO analysis do not portend that such methods will be developed in the near future, in September 2012, the European Commission proposed to amend the Directive 2001/110/ EC related to honey. The proposal describes pollen as a natural constituent of honey, not as an ingredient, which is in accordance with the Food and Agriculture Organization of the United Nations and World Health Organization criteria. If pollen is no longer an ingredient in honey, the quantification of GM pollen will be done in relation to honey in general; consequently, any special labelling of honey containing GMOs will not be necessary.

\section{REFERENCES:}

Ancel V., Bellocchi G., Berben G., Bertheau Y., Brera C., De Giacomo M., Janssen E., Kobilinsky A., Kozjak P., Macarthur R., Miraglia M., Onori R., Pia M., Papazova 
N., Rutar R., Taverniers I., Šuštar Vozlic J. (2009) GMO sampling strategies in the food and feed chain. In: Proceedings of the International Conference on CM and non-GM supply chains: their coexistence and traceability. Paris, France. 2-5 June 2009. pp. 35-37.

Bellocchi G., Ermolli M., Savini C., van den Eede G. (2009) GMO testing methods: analytical approaches, method validation and sampling strategy. In: Cauvain S., Young L. (Eds.) The ICC handbook of cereals, flour, dough \& product testing: methods and applications. DEStech Publication. Lancaster, PA, USA. pp. 279-289.

Bobis O., Marghitas L. A., Rakosy-Tican E. (2012) Incidence of Pollen from Genetically Modified Plants in Bee Products - A Review. Bulletin UASVM Animal Science and Biotechnologies 6(9): 1-2.

Brodmann P. (2008) DNA extraction from different matrices. Molecular Biology Methods for Traceability Purposes. In: TRACE dissemination workshop. BFR. Berlin, Germany. 18-19 December 2008. Available at: http://trace.eu.org/ws/berlin/Day 1 -05-DNA-extraktion.pdf

Broothaerts W., Corbisier P." Matayron G., Mazoua S., Schimmel H., Trapmann S., Vincent S., Emons H. (2008) A single nucleotide polymorphism in the adh 1 reference gene affects the quantitation of CM maize. 1st Global Conference on GMO analysis. Como, Italy. 27 June 2008. JRC - European Commission. Available at: http://gmoglobalconference.jrc. ec.europa.eu/2008/Presentations/Broothaerts.pdf

Bryant V. M., Jones G. D. (2001) The R-Values of Honey: Pollen Coefficients. Palynology 25: 11-28. DOl: 10.1080/01916122.2001.9989554

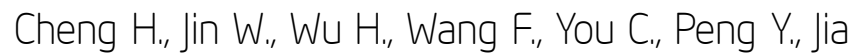
S. (2007) Isolation and PCR Detection of Foreign DNA Sequences in Bee Honey Raised on Genetically Modified Bt (cry 1 Ac) Cotton. Food and Bioproducts Processing 85(2): 141-145. DOl: 10.1205/ fbp06056

Chaouachi M., El Malki R., Berard A., Romaniuk M., Laval V., Brunel D., Bertheau Y. (2008a) Development of a real-time PCR method for the differential detection and quantification of four solanaceae in GMO analysis: potato (Solanum tuberosum), tomato (Solanum Iycopersicum), eggplant (Solanum melongena), and pepper (Capsicum annuum). Journal of Agricultural and Food Chemistry 56(6): 1818-28. DOl: 10.1021/jf073313n

Chaouachi M., Fortabat M. N., Geldreich A., Yot P., KerIan C., Kevdani N., Audeon C., Romaniak M., Bertheau Y. (2008b) An accurate real-time PCR test for the detection and quantification of cauliflower mosaic virus (CaMV): applicable in GMO screening. European Food Research and Technology 227: 789-798. DOl: 10.1007/s00217-007-0787-5

Chaouachi M., Alaya A., Ali I.B., Hafsa A. B., Nabi N., Bérard A., Romaniuk M., Skhiri F., Saïd K. (2013) Development of real-time PCR method for the detection and the quantification of a new endogenous reference gene in sugar beet "Beta vulgaris L.: GMO application. Plant Cell Report 32(1): 117-28. DOl: 10.1007/s00299-012-1346-5

Ciabatti I., Froiio A., Gatto F., Amaddeo D., Marchesi U. (2006) In-house validation and quality control of real-time PCR methods for GMO detection: a practical approach. Developments in Biologicals (Basel) 126: 79-86; discussion 324-5.

Council Directive 2001/110/EC of 20 December 2001 relating to honey. Official Journal of the European Communities 10, 12.1.2002: 47-52.

Court of Justice of the European Union (2011) Judgemment in Case C-442/09 Karl Heinz Bablok and Others v Freistaat Bayern. Press release No 79/1. Luxemburg. 6 September 2011. http://eur-lex.europa.eu/LexUriServ/LexUriServ. do?uri=CELEX:32001L0110:EN:HTML

Davison J. (2011) Honey-free Europe. Available at: http://ddata.over-blog.com/xxxyyy/1/39/38/37/ Honey-free-Europe_John_Davison_Nov15-2001. pdf

Dobbelaere W., de Graaf D. C., Peeters J. E., Jacobs F. J. (2001) Development of a fast and reliable diagnostic method for American foulbrood disease (Paenibacillus larvae subsp. larvae) using a 16S rRNA gene 
based PCR. Apidologie 32: 363-370. DOl: 10.1051/ apido:2001136

Eichner C. (201 1) Honey analysis in Lower Saxony. In: International Workshop on the consequences of the ECJ judgement on GM pollen in honey for GM crops and releases and cultivation in Germany and the EU. Berlin, Germany. 13-14 December 2011. Avaliable at: www.brasilapicola.com.br/files/honeyanalysis-in-lower-saxony.pdf

European Coexistence Bureau (2013) Summary of conclusions of the Sixth Plenary meeting of the Technical Working Group for Maize. Ref. Ares (2013)42162 - 14/01/2013. 9 pp.

European Commission (2004) Recommendation 2004/787/EC. Commission Recommendation of 4 October 2004 on technical guidance for sampling and detection of genetically modified organisms and material produced from genetically modified organisms as or in products in the context of Regulation (EC) No 1830/2003Text with EEA relevance. Official Journal L 34, 24/1 1/2004. p. 18.

European Commission (2010) Commission Recommendation of 13 July 2010 on guidelines for the development of national co-existence measures to avoid the unintended presence of GMOs in conventional and organic crops (2010/C 200/01). Official Journal C 200, 22/07/201 0. p. 1.

European Commission (2012a) Food: Commission proposes clearer rules on status of pollen in honey. Available at: http://europa.eu/rapid/press-release_ IP-12-992_en.htm

European Commission (2012b) Proposal for a Directive of the European Parliament and of the Council amending Council Directive 2001/1 10/EC relating to honey. Availableat: http://eur-lex.europa.eu/LexUriserv/LexUriServ.do?uri=COM:2012:0530:FIN:EN:PDF

European Commission (2013a) Short Term Outlook for EU arable crops, meat and dairy markets. 20 pp. Available at: http://ec.europa.eu/agriculture/ markets-and-prices/short-term-outlook/pdf/summer-2013_en.pdf
European Commission (2013b) Daily News of 2013-1 1-06. MEX/13/1 106. Available at: http://europa.eu/rapid/press-release_MEX-13-1 106_en.htm

European Food Safety Authority Panel on Genetically Modified Organisms (2011) Scientific opinion: Statement on the safety of MON 810 maize pollen occurring in or as food. EFSA Journal 201 1: 9(1 1): 24-34.

European Parliament and the Council of the European Union (2013) Clarifying the Status of Pollen in Honey: Substitute Impact Assessment of EC Directive Amending Council Honey Directive 2001/1 10/ EC. 66 pp. Available at: http://www.europarl.europa. eu/RegData/etudes/etudes/join/2013/514066/ IPOL-JOIN_ET\%282013\%29514066_EN.pdf

European Union Reference Laboratory for GM Food and Feed (2012) Verification Report on the extraction and analysis of GM pollen DNA in honey. 30 pp. Available at: http://gmo-crl.jc.ec.europa.eu/doc/ GM_Honey_REPORT_EUR-25524-EN.pdf

Fernandez I., Ortiz P. L. (1 994) Pollen contamination of honey by bees inside the hive. Grana 33: 282285. DOl: 10.1080/0017313940942901 1

Filodda F. (201 1) Honey Market in Europe. HonigVerbande.V. Available at: http://www.apinews.com/ pdf/apimondia201 1/economy/honey_market_in_ europe-frank_filodda.pdf

German Standard DIN 10742: 2011 -06 (201 1) DIN 10742. Analysis of honey - Guideline for sampling.

German Standard DIN 10760:2002 (2002) Determination of the relative pollen content of honey.

Grohmann L., Brünen-Nieweler C., Nemeth A., Waiblinger H. U. (2009) Collaborative trial validation studies of real-time PCR-based GMO screening methods for detection of the bar gene and the ctp2-cp4epsps construct. Journal of Agricultural and Food Chemistry 57(19): 8913-8920. D0l: 10.1021/jf901598r

Hofmann F., Epp R., Kalchschmid A., Kratz W., Kruse L., Kuhn U., Maisch B., Müller E., Ober S., Radtke J., Schlechtriemen U., Schmidt G., Schröder W., von der Ohe 
W., Vögel R., Wedl N., Wosniok W. (2010) Monitoring of Bt-Maize pollen exposure in the vicinity of the nature reserve Ruhlsdorfer Bruch in northeast Germany 2007 to 2008. Umweltwiss Schadst Forsch 22: 229-251. DOl: 10.1007/s12302-010-0133-6

Holst-Jensen A., De Loose M., Van den Eede G. (2006) Coherence between legal requirements and approaches for detection of genetically modified organisms (GMOs) and their derived products. Journal of Agricultural and Food Chemistry 54: 2799-2809. DOl: 10.1021/jf052849a

James C. (2012) Global Status of Commercialized Biotech/GM Crops: 2011 . The International Service for the Acquisition of Agri-biotech Applications (ISAAA) Brief No. 43. ISAAA: Ithaca. NY. 36 pp.

James C. (2013) Global Status of Commercialized Biotech/GM Crops: 2012. The International Service for the Acquisition of Agri-biotech Applications (ISAAA) Brief No. 44. ISAAA: Ithaca. NY. 18 pp.

Kluga L., Folloni S.Van den Bulcke M., Van den Eede G., Querci M. (2012) Applicability of the "Real-Time PCR-Based Ready-to-Use Multi-Target Analytical System for GMO Detection" in processed maize matrices. European Food Research and Technology 234(1): 109-1 18. DOl: 10.1007/s00217-01 1$1615-5$

Lanzelotti P. (2011) Implementation of the EC] judgement in the honey market practice: a technical study. In: International Workshop on the consequences of the EC) judgement on CM pollen in honey for GM crops and releases and cultivation in Germany and the EU. Berlin, Germany. 13-14 December 2011.

Laube I., Hird H., Brodmann P., Ullmann S., SchoneMichling M., Chisholm J., Broll H. (2010) Development of primer and probe sets for the detection of plant species in honey. Food Chemistry 118: 979-986. DOl: 10.1016/j.foodchem.2008.09.063

Linkiewicz A., Wisniewska l., Sowa S. (2006) Molecular analysis in detection and identification of genetically modified organisms (GMO). Biotechnologia 3(74): 44-52.
Lipiński Z., Farjan M., Zółltowska K., Polaczek B. (2008) Effects of dietary transgenic Bacillus thuringiensis maize pollen on hive worker honeybees. Polish Journal of Environmental Studies 17(6): 957 961.

Louveaux J., Maurizio A., Vorwohl G. (1970) Methods of Melissopalynology. Bee World 51: 125-131.

Louveaux J., Maurizio A., Vorwohl G. (1978) Methods of Melissopalynology. Bee World 59(4): 139-157.

Mano J., Harad M., Takabatake R., Furui S., Kitta K. Nakamura K., Akiyama H., Teshima R., Noritake H., Hatano S. (2012) Comprehensive GMO detection using real-time PCR array: single-laboratory validation. Journal of the Association of Official AnaIytical Chemists 95(2): 508-516. DOl: 10.5740/ jaoacint.1 1-388

Maurizio A. (1951) Untersuchungen über den Einfluss der Pollenernährung und Brutpflege und die Lebensdauer und den physiologischen Zustand der Bienen. In: Report of the XIVth International Beekeeping Congress. Leamington Spa, UK. p. 320.

Messean A., Angevin F." Gomez-Barbero M., Menrad K., Rodríguez Cerezo E. (2006) New case studies on the coexistence of GM and non-GM crops in European agriculture. Technical Report Series of the Joint Research Center of the European Commission EUR 22102 En. 112 pp.

Nowakowski J., Morse R. (1982) The behaviour of honey bees in sweet corn fields in New York state. American Bee Journal 122: 13-16.

Olivieri C., Marota I., Rollo F., Luciani S. (2012) Tracking Plant, Fungal, and Bacterial DNA in Honey Specimens. Journal of Forensic Sciences 57(1): 222-227. DOl: 10.1111/j.1556-4029.201 1.01 964.x

Paoletti C., Donatelli M., Kay S., Van den Eede, G. (2003) Simulating kernel lot sampling: the effect of heterogeneity on the detection of GMO contaminations. Seed Science and Technology 31: 629-638.

Piazza M. G., Persano Oddo L. (2004) Bibliographical review of the main European unifloral honeys. Apidologie 35 (Suppl. 1): 94-111. DOl: 10.1051/ apido:2004046 
Piccini C., D'Alessandro B., Antunez K., Zunino P. (2002) Detection of Paenibacillus larvae subspecies larvae spores in naturally infected bee larvae and artificially contaminated honey by PCR. World Journal of Microbiology and Biotechnology 18: 761-765.

Pla M., La Paz J. L., Peñas G., García N., Palaudelmàs M., Esteve T., Messeguer J., Melé E. (2006) Assessment of real-time PCR based methods for quantification of pollen-mediated gene flow from GM to conventional maize in a field study. Transgenic Research 15(2): 219-28. DOl: 10.1007/s 1 1248-005-4945-x

Prabucki J. (Ed.) (1998) Pszczelnictwo. Wydawnictwo promocyjne "Albatros". Szczecin. 900 pp.

Querci M., Foti N., Bogni A., Kluga L., Broll H., Van den Eede G. (2009) Real-Time PCR-Based Ready-toUse Multi-Target Analytical System for GMO Detection. Food Analytical Methods 2(4): 325-336. DOl: 10.1007/s12161-009-9093-0

Regulation No. 834/2007/EC of European Commission of 28 June 2007 on organic production. Official Journal L 189/1, 20.7.2007. p. 1.

Regulation No. 889/2008/EC of European Commission of 5 September 2008 laying down detailed rules for the implementation of Council Regulation (EC) No. 834/2007 on organic production and labelling of organic products with regard to organic production, labelling and control. Official Journal L 250, 18.9.2008. p. 1.

Regulation No 1829/2003/EC of European Parliament and the Council of the European Union. Office Journal of the European Union L 268/1, 18.10.2003. p. 1.

Regulation No 1830/2003/EC of European Parliament and the Council of the European Union. Office Journal of the European Union L 268/1, 18.10.2003. p. 24.

Ricciardelli d'Albore G. (1997) Textbook of melissopalynology. Apimondia Publishing House. Bucharest. 308 pp.
Roulston T. H., Cane J. H., Buchmann S. L. (2000) What governs protein content of pollen: pollinator preferences, pollen-pistil interactions, or phylogeny? Ecological Monographs 70(4): 617-643. DOl: 10.1890/0012-9615(2000)070[0617:WGPCOP]2 $.0 . \mathrm{CO}, 2$

Sabugosa-Madeira B., Abreu l., Ribeiro H., Cunha M. (2007) Bt Transgenic maize pollen and silent poisoning of the hive. Journal of Apicultural Research 46(1): 57-58. DOl: 10.3896//BRA.1.46.1.10

Sawyer R. W. (1 988) Honey identification. University College Cardiff Press. Cardiff, UK. 115 pp.

Schiemann J. (201 1) European measures on coexistence and experiences with their implementation. In: International Workshop on the consequences of the EC] judgement on GM pollen in honey for GM crops and releases and cultivation in Germany and the EU. Berlin, Germany. 13-14 December 2011.

Schnell B. I., Fraser M., Willerslev E., Gilbert M. P. T. (2010) Characterisation of insect and plant origins using DNA extracted from small volumes of bee honey. Arthropod-Plant Interactions 2: 107-116. DOl: 10.1007/s1 1829-010-9089-0

Scholdberg T. A., Burton D. D., Jenkins G. R. (2008) Identification of Suitable Endogenous Control Genes in Applications for Quantification of BiotechnologyDerived Traits in Maize Using Real-Time qPCR. In: 1 st Global Conference on GMO analysis. Como, Italy. 24-27 June 2008. Avaliable at: http://gmoglobalconference.jrc.ec.europa.eu/2008/Posters/T.2.33\%20 Scholdberg.pdf

Scholtens I. M., Kok E. J., Hougs L., Molenaar B., Thissen J. T., van der Voet H. (2010) Increased efficacy for in-house validation of real-time PCR GMO detection methods. Analytical and Bioanalytical Chemistry 396(6): 2213-2227. DOl: 10.1007/s00216009-3315-6

Stawiarz E., Wróblewska A. (2010) Melissopalynological analysis of multifloral honeys from the Sandomierska Upland area of Poland. Journal of Apicultural Science 54(1): 65-75. 
Ustawa z dnia 9 listopada 2012 o nasiennictwie. Dz.U. z 2012 poz. 1512.

Von der Ohe W., Oddo L. P., Piana M. L., Morlot M., Martin P. (2004) Harmonized methods of melissopalynology. Apidologie 35(Suppl. 1): S18-S25. DOl: 10.1051/apido:2004050

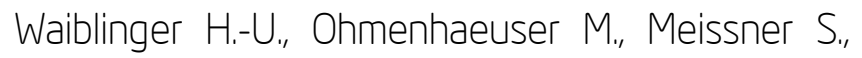
Schillinger M., Pietsch K., Goerlich O., Mankertz J., Lieske K., Broll H. (2012) In-house and interlaboratory validation of a method for the extraction of DNA from pollen in honey. Journal für Verbraucherschutz und Lebensmittelsicherheit 7(3): 243-254. DOl: 10.1007/s00003-012-0765-0

Wróblewska A. (2002) Rośliny pożytkowe Podlasia w świetle analizy pyłkowej produktów pszczelich Rozprawy Naukowe Akademii Rolniczej w Lublinie 264: 1-83.
Wróblewska A., Warakomska Z., Kamińska M. (2010) The pollen spectrum of bee bread from the Lublin region (Poland). Journal of Apicultural Science 54(2): 81-89.

Wysocka A. (2009) Próba oceny oddziaływania pyłku transgenicznej kukurydzy MON 810 na pszczołę miodną (Apis mellifera L.). M.A. thesis. Dąbrowski Z. T. (supervisor) University of Life Sciences. Faculty of Horticulture and Landscape Architecture. Warsaw.

Žel J., Milavec M., Morisset D., Plan D., Van den Eede G., Gruden K. (2012) How to Reliably Test for GMOs. Springer Briefs in Food, Health, and Nutrition. 95 pp. DOl: 10.1007/978-1-4614-1390-5_1 